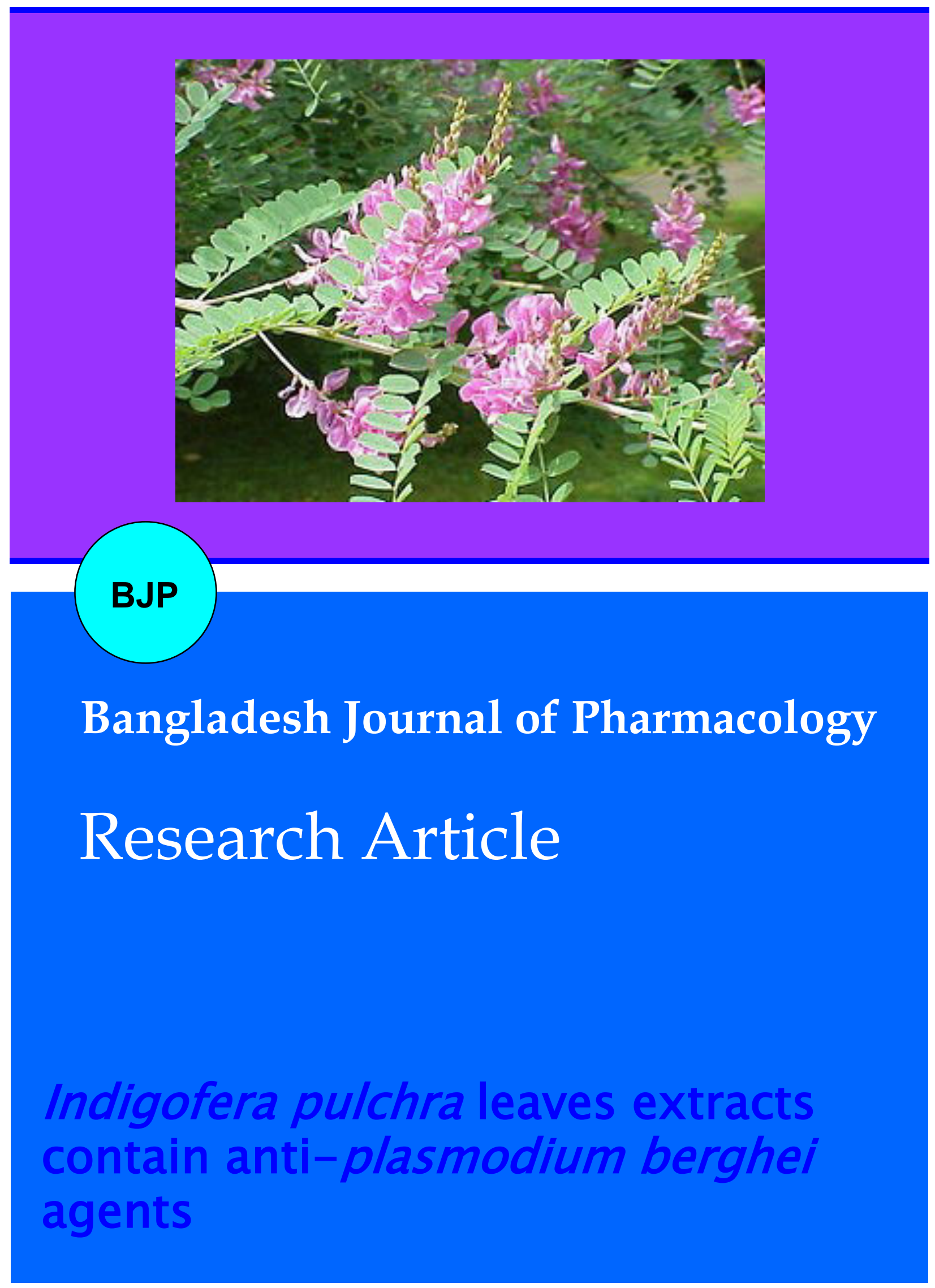


Abstracted/indexed in Academic Search Complete, Agroforestry Abstracts, Asia Journals Online, Bangladesh Journals Online, Biological Abstracts, BIOSIS Previews, CAB Abstracts, Current Abstracts, Directory of Open Access Journals, EMBASE/Excerpta Medica, Google Scholar, HINARI (WHO), International Pharmaceutical Abstracts, Open J-gate, Science Citation Index Expanded, SCOPUS and Social Sciences Citation Index

ISSN: 1991-0088 (Online)

\title{
Indigofera pulchra leaves extracts contain anti-plasmodium berghei agents
}

\author{
Sani Ibrahim', Mohammed A. Ibrahim¹, Aliyu M. Musa², Abubakar B. Aliyu³, Nura \\ S. Haruna ${ }^{1}$ and Azubuike I. Okafor'1
}

${ }^{1}$ Department of Biochemistry, Ahmadu Bello University, Zaria, Nigeria; ${ }^{2}$ Department of Pharmaceutical and Medicinal Chemistry, Ahmadu Bello University, Nigeria; ${ }^{3}$ Department of Chemistry, Ahmadu Bello University, Zaria, Nigeria.

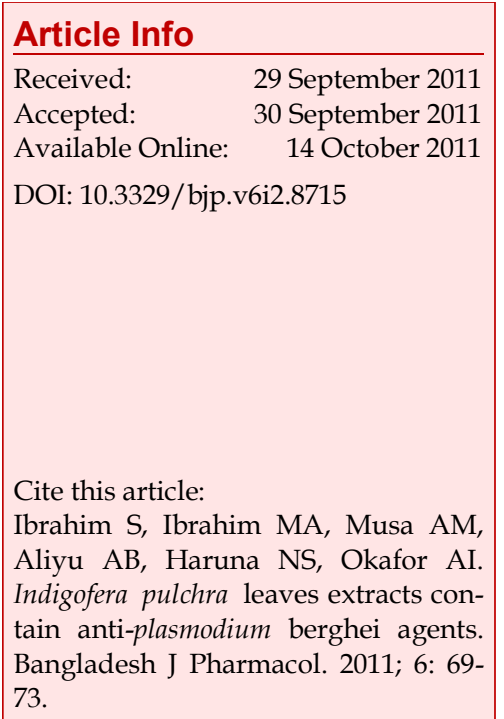

\begin{abstract}
This study was conducted to investigate the anti-plasmodium berghei activities of some extracts from Indigofera pulchra leaves. Six groups of mice were intraperitoneally infected with chloroquine sensitive $P$. berghei (NK 65) among which two groups were orally treated with 100 and $200 \mathrm{mg} / \mathrm{kg}$ body weight of methanol leaves extract while another two groups were treated with 100 and $200 \mathrm{mg} / \mathrm{kg}$ of $n$-butanol fraction derived from the methanol extract. Another infected group was treated with chloroquine $(25 \mathrm{mg} / \mathrm{kg})$ whereas the remaining infected group was left untreated. All infected treated groups possessed a significantly $(\mathrm{p}<0.05)$ lowered number of parasitized erythrocytes than the infected untreated group throughout the experimental period except at day 6 post-infection. However, the $200 \mathrm{mg} / \mathrm{kg} n$-butanol fraction treated group demonstrated a persistently lower number of parasitized erythrocytes than other extract-treated groups after day 9 post infection to the termination of the experiment. The $P$. berghei was found to induce anemia whose severity was significantly $(\mathrm{p}<0.05)$ ameliorated by all the treatments. It was concluded that the methanol extract and $n$-butanol fraction of I. pulchra contains anti-P. berghei phytochemicals that could ameliorate the parasite-induced anemia.
\end{abstract}

\section{Introduction}

Despite the incessant global efforts to fight parasitic infections and the attempts to eliminate the causative organisms, malaria remains a major public health problem in Africa and globally responsible for one to three million death and 300 to 500 million infections annually (Krishna et al., 2009; Verma et al., 2011). The disease is caused by intracellular protozoan parasites from the genus Plasmodium and among the different species, Plasmodium berghei (rodent malaria parasite) provides a well established experimental model of malaria infection (Margarida et al., 2006) because it produces a disease thought to closely mimic the features of malaria infection in human (Van der Heyde et al., 2006).
The treatment of malaria presently relies on chemotherapy as the only available option because the most successful malaria vaccine was only partially efficient and short lived (Kayano et al., 2011). However, the existing chemotherapeutic strategies are faced with lots of challenges that include, but not limited to, drug toxicity and development of drug resistant strains of the parasite. Furthermore, no new class of antimalarial has been introduced since 1996. Thus, the importance of identifying new lead compounds that could potentially be used for the development of chemotherapeutic drugs against this disease cannot be overemphasized.

The use of plant preparations for the treatment of diseases still holds a strong potential since the influence 
of natural products upon drug discovery is impressive and a number of clinically active drugs are either natural products or have a natural product pharmacophore (Koehn and Carter, 2005). Ethnopharmacological reports revealed a number of tropical plants to contain potent antimalarial agents (Onaku et al., 2011; Rasoanaivo et al., 2011). In fact, the compounds most widely used to treat malaria, quinine and artemisinin, are originally derived from traditional medicine and plant extracts (Carmago et al., 2009). These suggest the need of exploring medicinal plants as leads for the development of new source of antimalarial agents.

Indigofera pulchra Willd (Papilionaceae) is an erect stiff, grey-pubescent softly wooded under-shrub that grows up to 1-1.5 $\mathrm{m}$ high. It is widely distributed from Senegal to Nigeria and over Eastern and central Africa from Ethiopia to Angola (Burkhill, 1995). In ethnomedicine, the leaves are used to treat infected wound (Burkill, 1995), while the decoction of the aerial parts is used to treat snake-bite (Sule et al., 2003), inflammatory responses (Abubakar et al., 2007) and malaria (Adamu et al., 2005; Asase et al., 2005). However, scientific information on the antimalarial activity from any part of this plant, and indeed other plants of Indigofera family, has not been documented. In this study, we report the in vivo anti-P. berghei activity of methanol extract and $n$-butanol fraction from I. pulchra leaves.

\section{Materials and Methods}

\section{Plant material}

I. pulchra fresh leaves was collected from Samaru-Zaria, Kaduna state, Nigeria in the month of August, 2010 and was identified to the species level at the herbarium unit of the Biological Sciences Department, Ahmadu Bello University Zaria-Nigeria where a voucher specimen (No. 410) was deposited. The leaves were thoroughly washed and shade-dried to a constant weight in our laboratory. The dried leaves were pounded to fine powder using pestle and mortar and then stored in dry containers until needed.

\section{Samples preparation}

The air-dried powdered materials sample (500 g) was exhaustively extracted with $80 \%$ methanol (maceration) for a week. The extract was filtered using Whatman filter paper (No. 2) and concentrated on a Büchi rotary evaporator at $40^{\circ} \mathrm{C}$ under reduced pressure to yield a residue $(52.0 \mathrm{~g})$ referred to as methanol extract. Forty grams of the methanol extract was suspended in distilled water and filtered to get a water soluble part which was extracted with ethyl acetate $(2 \times 500 \mathrm{~mL})$ followed by $n$-butanol $(4 \times 500 \mathrm{~mL})$ to give $0.9 \mathrm{~g}$ and 2.4 $\mathrm{g}$ of ethyl acetate and $n$-butanol fractions respectively.

\section{Experimental animals}

The protocol employed met the guidelines governing handling of laboratory animals of Ahmadu Bello University, Zaria (ABUZ), Nigeria. Thirty five male swiss albino mice weighing 18-22 g were obtained from the animal house of Department of Biochemistry, Faculty of Sciences, ABUZ, Nigeria. The animals were kept in well ventilated laboratory cages with 12 hours day/night cycles and maintained on a ration containing commercial poultry feed (Vital feeds, Jos). Water was also supplied ad libitum.

\section{Plasmodium berghei and infection of experimental animals}

Blood stage samples of chloroquine sensitive P. berghei NK 65 used for this study was obtained from the Protozoology laboratory, Department of Veterinary Parasitology and Entomology, Faculty of Veterinary Medicine, ABUZ, Nigeria. It was maintained in our laboratory by serial passage in mice. The experimental animals were infected through an intraperitoneal injection of approximately $10^{4}$ infected red cells in cold phosphate buffered saline (Ene et al., 2009).

\section{In vivo anti-P. berghei study}

Thirty five mice were randomly divided into seven groups of five mice each. Mice in six of the groups were each infected, while mice in the remaining one group were uninfected. A pair of infected groups was orally treated with $100 \mathrm{mg} / \mathrm{kg}$ body weight of the methanol extract and the $n$-butanol fraction whereas another pair of infected groups was orally treated with $200 \mathrm{mg} / \mathrm{kg}$ of the methanol extract and the $n$-butanol fraction. One infected group was treated with $25 \mathrm{mg} / \mathrm{kg}$ of chloroquine and the remaining group of infected mice was left untreated. All treatments were given daily from day 5 post infection (pi) to the end of the experiment on day 14 pi.

\section{Samples collection and analyses}

Tail blood was collected daily for the estimation of parasitemia (Ene et al., 2009) using the Giemsa-stained thin blood smears technique and packed cell volume was determined using the microhematocrit method at Days 0 and 14 pi.

\section{Statistical analysis}

The results are presented as mean \pm SD of five replicate values. Students' t-test was used to compare paired means and a difference was considered statistically significant when $\mathrm{p}<0.05$.

\section{Results}

The parasitemia profile of infected groups treated with either the methanol extract, $n$-butanol fraction or chloroquine is presented in Figure 1. The P. berghei 


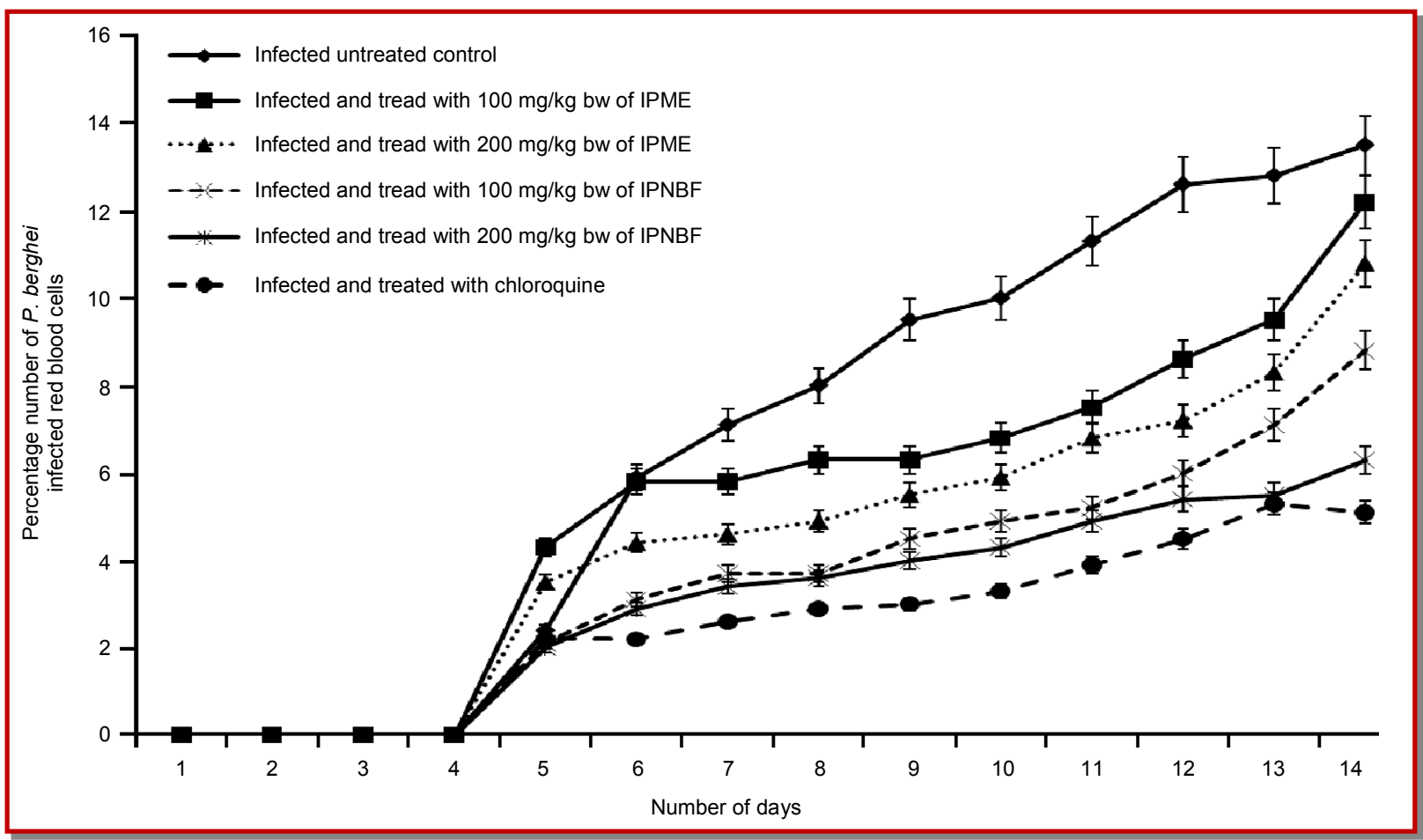

Figure 1: Effect of I. pulchra leaves extracts on the course of $P$. berghei infection in mice. All Data are presented as mean \pm SD. IPME and IPNBF means methanolic extract and $n$-butanol fraction of I. puchra leaves respectively

parasites were first detected in all groups on Day 5 pi and progressively increased in the infected untreated group. All infected treated groups demonstrated a significantly $(p<0.05)$ lowered number of parasitized erythrocytes than the infected untreated group throughout the experimental period except at day 6 pi where no significant difference $(p>0.05)$ was observed with $100 \mathrm{mg} / \mathrm{kg}$ methanol extract treated group. However, the number of $P$. berghei infected red blood cells is consistently lower in the $200 \mathrm{mg} / \mathrm{kg} \mathrm{n}$-butanol fraction treated mice than other groups of treated mice. The $P$. berghei infection in this work caused significant $(p<0.05)$ drop in the packed cell volume of infected mice, indicative of anemia but the severity of the anemia observed in the infected untreated group is significantly $(\mathrm{p}<0.05)$ higher than those of the methanol extract, $n$-butanol fraction and chloroquine treated animals (Table I). Furthermore, the $200 \mathrm{mg} / \mathrm{kg} n$ butanol fraction treated group exhibited a significantly $(p<0.05)$ lower degree of anemia than the methanol extract treated groups that was statistically similar to the chloroquine treated group.

\section{Table I}

Effects of $I$. pulchra leaves extracts on the levels of packed cell volume of $P$. berghei infected mice

\begin{tabular}{|c|c|c|c|c|c|c|c|}
\hline \multirow[t]{2}{*}{ Parameters } & \multicolumn{7}{|c|}{ Groups $(\mathrm{n}=7)$} \\
\hline & $\begin{array}{l}\text { Normal } \\
\text { control }\end{array}$ & $\begin{array}{c}\text { Infected } \\
\text { untreated } \\
\text { control }\end{array}$ & $\begin{array}{l}\text { Infected and } \\
\text { treated with } \\
100 \mathrm{mg} / \mathrm{kg} \\
\text { bw of IPME }\end{array}$ & $\begin{array}{l}\text { Infected and } \\
\text { treated with } \\
200 \mathrm{mg} / \mathrm{kg} \\
\text { bw of IPME }\end{array}$ & $\begin{array}{l}\text { Infected and } \\
\text { treated with } \\
100 \mathrm{mg} / \mathrm{kg} \\
\text { bw of IPNBF }\end{array}$ & $\begin{array}{l}\text { Infected and } \\
\text { treated with } \\
200 \mathrm{mg} / \mathrm{kg} \\
\text { bw of IPNBF }\end{array}$ & $\begin{array}{c}\text { Infected } \\
\text { treated with } \\
\text { chloroquine }\end{array}$ \\
\hline Initial PCV (\%) & $41.5 \pm 1.7$ & $41.3 \pm 3.2$ & $41.3 \pm 1.8$ & $45.5 \pm 0.9$ & $45.5 \pm 3.6$ & $44.6 \pm 1.3$ & $42.7 \pm 1.4$ \\
\hline Final PCV (\%) & $49.1 \pm 3.8$ & $25.3 \pm 2.9$ & $33.1 \pm 2.6$ & $37.2 \pm 1.5$ & $39.1 \pm 1.8$ & $39.9 \pm 2.4$ & $39.8 \pm 3.0$ \\
\hline $\begin{array}{l}\text { *Percentage } \\
\text { change in PCV } \\
(\%)\end{array}$ & $+18.1 \pm 2.6^{a}$ & $-38.7 \pm 4.0^{\mathrm{b}}$ & $-19.9 \pm 1.9 c$ & $-18.4 \pm 2.1 c$ & $-14.2 \pm 1.7^{\mathrm{d}}$ & $-10.7 \pm 1.2 \mathrm{e}$ & $-10.0 \pm 1.9 \mathrm{e}$ \\
\hline \multicolumn{8}{|c|}{$\begin{array}{l}\text { All values are presented as mean } \pm \text { SD and values with different superscripts letters }(\mathrm{a}, \mathrm{b}, \mathrm{c}, \mathrm{d}) \text { within a row are statistically different }(\mathrm{p}<0.05) \text {; } \\
\text { *These values represent the percentage differences between initial and terminal PCV values and positive sign }(+) \text { indicate increase while negative } \\
\text { sign (-) indicate decrease; IPME and IPNBF means methanol extract and } n \text {-butanol fraction of } I \text {. puchra leaves respectively }\end{array}$} \\
\hline
\end{tabular}




\section{Discussion}

Medicinal plants are important in the identification of chemical leads for the development of new generation of antimalarial drugs. We report herein the anti-P. berghei activities of leaves extract of I. pulchra, a plant use in the traditional treatment of malaria infection.

Most drugs and natural products with high in vitro activity may show no in vivo activity and vice versa, due to the biotransformation of plant materials that may convert active therapeutic molecules to inactive ones (Ibrahim et al., 2010), we therefore tested the extracts for in vivo activity so that a safer statement on the antimalarial action of this plant can be made. The observed anti- $P$. berghei activity of $I$. pulchra extracts suggest that the extracts contain some phytochemicals that could interfere with the survival of the parasites in vivo. The ability of the $n$-butanol fraction to exhibit a consistently higher antimalarial activities than the methanol extract at all the doses tested might indicate that the active compounds are concentrated in the $n$ butanol fraction and/or the methanol extract contains some components that could antagonize the antimalarial compound(s) of this plant. However, fractionation with ethyl acetate successfully removed most of the antagonists and this is evident by the lack of anti- $P$. berghei activity of the ethyl acetate fraction (results not shown) as well as the enhanced activity of $n$-butanol fraction. Although this work did not involve active compound(s) determination but reagent-based chemical analysis of the methanol extract previously revealed the presence of flavonoids, tannins, saponins, steroids, triterpenes and dihydrostilbenes nucleus ( Musa et al., 2010) and previous reports have attributed the antimalarial activities of some plants to the flavonoids, tannins and triterpenes (Kayano et al., 2011; Ene et al., 2009). However, the ethyl acetate fraction has been found to contain flavonoids and tannins with no steroidal nucleus (Tanko et al., 2009) and thus, the antimalarial activity of the $n$-butanol fraction could be linked, at least in part, to the triterpenes and/or dihydrostilbenes. Previous phytochemical studies on the methanol extract of this plant led to the isolation of lupeol and dihydrostilbenes (Musa et al., 2008).

The anemia observed in the P. berghei infected mice is an important feature of plasmodium infections (Becker et al., 2004). Several factors contribute to the development of anemia among which is increased lipid peroxidation as a consequence of oxidative damage to the membrane components of erythrocytes (Dondorp et al., 1999; Omedeo-sale et al., 2003). The amelioration of the $P$. berghei induced anemia by both the methanol extract and the $n$-butanol fraction could be linked to the reduction of number of parasitized erythrocytes caused by the extracts since a linear relationship was observed between the degree of parasitemia and severity of anemia in an anti-protozoan study (Ibrahim et al., 2010). It is also possible that the extracts contain some antioxidative components that could prevent the P. bergheiassociated oxidative damage to erythrocytes components. We have previously observed the amelioration of $P$. berghei induced anemia by an anti-oxidant vitamin (Ibrahim et al., 2011).

\section{Conclusion}

n-Butanol soluble phytochemical(s) derived from the crude methanol leaves extract of I. pulchra possess anti$P$. berghei activity and could ameliorate the diseaseinduced anemia.

\section{Acknowledgement}

We acknowledge Dr. Md. Atiar Rahman, University of Chittagong, Bangladesh, for the useful comments on the manuscript.

\section{References}

Adamu HM, Abayeh OJ, Agbo MO, Abdullahi AL, Uba A, Dukku HU, Wufem BM. An ethnobotanical survey of Bauchi State herbal plants and their antimicrobial activity. J Ethnopharmacol. 2005; 99: 1-4.

Abubakar MS, Musa AM, Ahmed A, Husaini IM. The perception and practice of traditional medicine in the treatment of cancers and inflammations by the Hausa and Fulani tribes of Northern Nigeria. J Ethnopharmacol. 2007; 111: 625-29.

Asase A, Oteng-Yeboah AA, Odamtten GT, Simmonds MSJ. Ethnobotanical study of some Ghanaian anti-malarial plants. J Ethnopharmacol. 2005; 99: 273-79.

Becker K, Tilley L, Vennerstrom JL, Roberts D, Rogerson S, Ginsburg H. Oxidative stress in malaria parasite-infected erythrocytes: Host-parasite interactions. Int J Parasitol. 2004; 34: 163-89.

Burkill HM. The useful plants of West Tropical Africa. Royal Botanic Garden Kew, 1995, pp 361-84.

Camargo LMA, Oliveira S, Basano S, Garcia CRS. Antimalarials and the fight against malaria in Brazil. Ther Clin Risk Manag. 2009; 5: 311-17.

Dondorp AM, Angus BJ, Chotivanich K, Silamut K, Ruangveerayuth R, Hardeman MR, Kager PA, Vreeken J, White NJ. Red blood cell deformability as a predictor of anemia in severe falciparum malaria. Am J Trop Med Hyg. 1999; 60: 733-37.

Ene AC, Atawodi SE, Ameh DA, Ndukwe GI, Kwanashie HO. Bioassay-guided fractionation and in vivo antiplasmodial effect of fractions of chloroform extract of Artemisia maciverae Linn. Acta Trop. 2009; 112: 288-94.

Kayano ACA, Lopes SCP, Bueno FG, Cabral EC, Souza-Neiras 
WC, Yamauchi LM, Foglio MA, Eberlin MN, Mello JCP, Costa FTM. In vitro and in vivo assessment of the antimalarial activity of Caesalpinia pluviosa. Malar J. 2011; 10: 112.

Koehn FE, Carter GT. The evolving role of natural products in drug discovery. Nat Rev Drug Discov. 2005; 4: 206-20.

Krishna AP, Chandrika SK, Kumar S, Acharya M, Patil SL, Variation in common lipid parameters in malaria infected patients. Indian J Physiol Pharmacol. 2009; 53: 271-74.

Ibrahim MA, Aliyu AB, Sallau AB, Bashir M, Yunusa I. and Umar TS. Senna occidentalis leaf extract possesses antitrypanosomal activity and ameliorates the trypanosomeinduced anemia and organ damage. Pharmacog Res. 2010; 2: $175-80$.

Ibrahim MA, Zuwahu MMB, Isah MB, Jatau ID, Aliyu AB, Umar IA. Effects of vitamin E administration on Plasmodium berghei induced pathological changes and oxidative stress in mice. Trop Biomed. 2011; (In press).

Margarida C, Silva P, Maria F, Maria MM. Infection by and protective immune responses against Plasmodium berghei ANKA are not affected in macrophage scavenger receptors a deficient mice. BMC Microbiol. 2006; 6: 1-5.

Musa AM, Haruna AK, Ilyas M, Ahmadu A, Gibbons S, Rahman MM. Dihydrostilbenes from Indigofera pulchra. Nat Prod Comm. 2008; 3: 805-08.

Musa AM, Sule MI, Ilyas M, Iliya I, Yaro AH, Magaji MG, Aliyu AB, Abdullahi MI, Hassan HS. Analgesic and antiinflammatory studies of the methanol extract of Indigofera Pulchra. Res J Medicine Med Sci. 2010; 5: 106-10.
Omodeo-Sale MF, Motti A, Basilico N, Parapini S, Olliaro P. Accelerated senescence of human erythrocytes cultured with Plasmodium falciparum. Blood 2003; 102: 705-11.

Onaku LO, Attama AA, Okore VC, Tijani AY, Ngene AA, Esimone CO. Antagonistic antimalarial properties of pawpaw leaf aqueous extract in combination with artesunic acid in Plasmodium berghei-infected mice. J Vec Borne Dis. 2011; 48: 96-100.

Rasoanaivo P, Wright CE, Wilcox ML, Gilbert B. Whole plant extracts versus single compounds for the treatment of malaria: Synergy and positive interactions. Malar J. 2011; 10 (Suppl 1): S4.

Sule MI, Pateh UU, Haruna AK, Garba M, Ahmadu AA, Adamu AK. Plants used in Hausa traditional medicine in Northern Nigeria. J Trop Biosci. 2003; 3: 17-20.

Tanko Y, Abdulaziz MM, Adelaiye AB, Fatihu MY, Musa KY. Effects of ethyl acetate portion of Indigofera pulchra leaves extract on blood glucose levels of alloxan-induced diabetic and normoglycemic Wistar rats. Asian J Med Sci. 2009; 1: 10 -14 .

Van der Heyde HC, Nolan J, Combes V, Gramaglia I, Grau GE A unified hypothesis for the genesis of cerebral malaria: Sequestration, inflammation and hemostasis leading to microcirculatory disfunction. Trends Parasitol. 2006; 22: 503 -08 .

Verma G, Dua VK, Agarwai DD, Atul PK. Anti-malarial activity of Holarrhena antidysenterica and Viola canescens, plants traditionally used against malaria in the Garhwal region of north-west Himalaya. Malar J. 2011; 10: 20. 